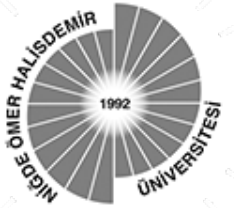

Araştırma Makalesi
Ömer Halisdemir Üniversitesi İktisadi ve İdari Bilimler Fakültesi Dergisi Yll: 2019 Cilt-Sayl: 12(4) ss: 578-588

\section{Academic Review of Economics and Administrative Sciences}

Year: 2019 Vol-Issue: 12(4) pp: 578-588

http://dergipark.gov.tr/ohuiibf/

\title{
ReSERVE Adequacy In TuRKey: A STUdy ON Comparison Of THE RESERVES With IMPORTS AND SHORT-TERM EXTERNAL DEBT*
}

Esra N. KILCI ${ }^{1}$

\begin{abstract}
The changes in the international reserves of a country, which reflect the financial power of an economy and considered significantly by international investors, are of great importance in terms of financial stability and are taken into consideration increasingly in the academic literature. Two of the traditional criteria used by the International Monetary Fund to assess reserve adequacy is to compare the international reserve level of a country with the optimal reserve amount, which represents \%25 of the annual imports and to compare net international reserve level with short-term external debt. The objective of this study is to investigate the international reserve adequacy in Turkey over the period of 2011:Q3-2018:Q4 based on this approaches by employing Fourier Granger causality test proposed by Enders and Jones (2016). The findings of the analysis indicate that while the reserves are adequate in Turkey according to the first approach, the reserves seem inadequate when taken into account the second approach in the relevant period.
\end{abstract}

Key Words : reserves adequacy, import, short-term external debt, structural breaks

Jel Classification :E52, E58, E66

\footnotetext{
* This paper is a revised and expanded version of a study entitled 'A Study on Assessment of the Reserve Adequacy: Evidence from Turkey' presented at the 20th Annual Conference on Finance and Accounting (ACFA 2019), which was held on May, 24, 2019 in Prague, Czech Republic.

${ }^{1}$ Assist. Prof. Dr., Istanbul Arel University, Faculty of Economics and Administrative Sciences, Department of International Trade and Finance, esrakilci@arel.edu.tr, ORCID: 0000-0002-2239-4560.
} 


\title{
TÜRKIYYE REZERV YETERLILİĞİ: REZERVLERIN İTHALAT Ve Kisa VADELİ Diş BorÇLARLA KarşıLAŞTIRILMASI ÜzERINE Bír ANALIz
}

\begin{abstract}
$\ddot{\partial} z$
Ülke ekonomisinin finansal gücünün bir göstergesi olan ve uluslararasl yatırımcllar tarafindan önemle dikkate alınan uluslararası rezervlerdeki değişimler, finansal istikrar açısından büyük öneme sahiptir ve akademik literatürde yaygin şekilde çallş̧lmaktadır. Ülkelerin rezerv yeterliliğinin hesaplanmasında, Uluslararası Para Fonu (IMF) tarafindan, uluslararast rezervleri, ylllk ithalatin $\% 25$ 'i oraninda belirtilen optimal rezerv seviyesi ve net uluslararası rezervleri, kusa vadeli dış borç toplamıyla karşılaştırmak şeklinde iki geleneksel yaklaşım kullanılmaktadır. Bu çalışmanın amacı, 2011:Ç3-2018:Ç4 döneminde Türkiye'de uluslararası rezervlerin yeterliliğini, Enders and Jones (2016) tarafindan gelişstirilen Fourier Granger nedensellik testini kullanarak araştırmaktır. Çalışma sonuçlarına göre, ilk yaklaşıma göre rezervler yeteliyken, ikinci yaklaşım dikkate alındığında rezervlerin yeterli olmadı̆̆g görülmektedir.
\end{abstract}

$\begin{array}{ll}\text { Anahtar kelimeler } & : \text { rezerv yeterliliği, ithalat, kısa vadeli dış borç, yapısal kırılmalar } \\ \text { Jel Sinıflandırması } & : \text { E52, E58, E66 }\end{array}$

\section{INTRODUCTION}

The prime of the reserve adequacy literature goes back to 1970's in which the focus was mainly on import-based measures and short term capital flows. In the following period, as a result of changing global conditions, it became necessary to update traditional approaches. Monetary authorities started to focus on assessing which level of reserves is optimal for creating a buffer stock against financial crises. In the mid 1990's, reserves in several ratios with other economic variables had turned out to be useful crisis predictors. For emerging market economies, comparison the reserves with three months of imports was often used. On the other hand, reserve levels play key role in determining the degree of private sector involvement. One of the critical lessons of Asian financial crisis was that countries' vulnerability to the capital withdrawals could be reduced by better management of their reserves and liabilities. Therefore, it has been increasinly recognised that it is essential to take into consideration the importance of capital outflows and to relate the size of reserves to a country's short-term external debt. In particular, in the economies which use external funds by borrowing in international markets, that ratio appears to be very important indicator of reserve adequacy (IMF, 2001).

Many emerging market economies need a stream of U.S. dollar financing because of current imbalances or the external debt payments. U.S. dollar financing arrangements become more difficult when the Federal Reserve Bank (FED) tightens monetary policy and withdraws liquidity. Therefore, borrowers need larger amounts of the local currency to acquire the same amount of U.S. dollar liquidity. The central banks in emerging market economies try to hold reserves as liquid foreign currency denominated assets in order to avoid from this external instability. When it becomes hard to provide funds from foreign lenders, these foreign exchange reserves can supply foreign exchange liquidity to domestic borrowers and stabilize the value of the domestic currency. Therefore, foreign exchange reserves are defined a safety net to guard against currency instability, when the central banks in advanced economies as FED tightens monetary policy. It is essential that emerging market economies decide which level of foreign exchange reserves is adequate in order to guard their local currency against fluctuations in foreign monetary policy and liquidity (Davis et al, 2018).

In the last two decades, the financial crises experienced in emerging market economies have contributed to the increase of the importance of reserves and led these economies to increase their reserves, regardless of whether the fixed or floating exchange rate regime was implemented. As a 
result of the implementation of expansionary monetary policies, the abundance of global liquidity and the increase in capital flows, there has been an upward trend in these economies. While the fact that the central bank reserves are above the optimal level is not desired due to the opportunity cost, inadequacy of the reserves which lead to the deterioration of investors' risk perception, the volatility in capital flows, the increasing concerns about the sustainability of external debt can make these economies more vulnerable to the financial crises (IMF, 2011). Despite of the opportunity cost, one of the major reasons why adequacy of international reserves are of great importance is that these reserves increase the resistance against financial fluctuations. According to the definition made by the IMF, international reserves are the sources that can be used and controlled by the monetary authorities in order to finance the balance of payments deficits, to control the fluctuations in foreign exchange rates directly and to regulate some imbalances indirectly (IMF, 1993).

As stated in the report published by the Central Bank of the Republic of Turkey, central banks demand reserves for reasons such as limiting the adverse effects of possible financial shocks on the country's economy, minimizing the problems which may arise from current account and capital account transactions, making external debt payments, supporting monetary and exchange rate policies and intervening in foreign exchange markets (CBRT, 2011). In this respect, the CBRT, manages the foreign currency and gold reserves within the framework of monetary policy objectives. Taking into account the priorities of investment, liquidity and returns, the CBRT carries out all banking activities in domestic and international markets including gold, foreign currency, securities, derivatives trading and borrowing and lending transactions (CBRT, 2001).

In fixed exchange rate regimes in which the central banks intervene to the markets to protect the pre-specified parity, if the country's imports are greater than the exports, the current account balance will be negative and the reserves will decrease. Similarly, if the exports are more than imports, the country reserves will increase. On the other hand, in floating exchange rate regimes, foreign exchange rates are determined based on supply and demand and there seems no significant change in reserves. In case of limited interventions, policies tend to approach the free-floating exchange rate system and changes in official reserves will be relatively reduced (Yaman, 2003). There is typically no need for central bank intervention or no need to hold reserves and it is expected to decrease reserve requirment in floating exchange rate regimes on the contary to the fixed exchange rate regimes. However, it is important that these countries have sufficient reserves because of the fact that the vulnerability of emerging market economies to financial crises is high and the excessive volatility in capital flows and foreign exchange rates can easily bring these economies to the verge of a financial crisis. In addition, it is emphasized in the academic literature that reserves have a positive role in the recovery process in the post-crisis period.

There are several criteria in the financial literature on evaluating reserve adequacy of emerging market economies. Examples of traditional measures include the ratio of reserves to short-term external debts, the ratio of reserves to money supply and the ratio of reserves to imported goods and services. On the other hand, because it is considered that these methods reflect the risks one-sided, a new method which has been called the International Monetary Fund metric has been developed by the IMF, which evaluate these risks together and also covers some other risks that may put pressure on the balance of payments (CBRT, 2011). The IMF risk-weighted metric of reserve adequacy benchmarked reserves not only against traditional metrics such as short-term external debt and imports but also against broad money to take into consideration the risk of capital flights (European Central Bank, 2018).

In this respect, the IMF examined the amount of foreign exchange reserves required by emerging market economies as a precautionary liquidity against potential risks that might put pressure on the balance of payments. This new metric incorporating traditional approaches and covering different risks also take into consideration past country experiences and based on scenario analyses, regression analyses and information taken from the countries' responsible authorities (Eren, 2017). Finally, it suggested that many emerging market economies appeared better placed to overcome the sudden stops or flight shocks. However, there are some countries whose reserves are still below the proposed minimum reserve adequacy requirements. (ECB, 2018). 
As mentioned above, according to the ratio of reserves to imported goods and services, the comparison of $\% 25$ of annual imports with the reserve level is one of the approaches used by the IMF to evaluate the reserve adequacy of countries. Accordingly, if the amount of reserves covers the $25 \%$ of annual imports, it is considered sufficient (Movchan, 2002). The other approach is to compare the net international reserves with the short-term external debt which will be repaid in one year period (Egilmez, 2017). In this regard, capability of a country to rollover its external debt which is referred to as debt tolerance is very important. When the short-term external debt has a great proportion in total debts, the country can have difficulties especially in the financial stress periods. If the reserves are sufficient, it means that the country can easily pay its short-term external debt. The objective of this study is to investigate the adequacy of reserves in Turkey by employing Fourier KPSS unit root test and Fourier Granger causality test by using quarterly data set belonged to the period of 2011:Q12018:Q4. Both these tests take into account the impact of multiple structural breaks.

The study has the following structure. After the literature review in Section 2, the Section 3 presents the data set and the methodology for the model which we apply to analyze the causality relationship between reserves, optimal reserve level and short-term external debt. Section 4 represents the results and the comments relating to the relationship. Finally, the last section outlines the main conclusions.

\section{LITERATURE REVIEW}

The changes in the international reserves of a country, which reflect the financial power of an economy and considered significantly by international investors, are of great importance in terms of financial stability and are taken into consideration increasingly in the academic literature. Below are the studies which focus on the size of the reserves and reserves adequacy.

Yaman (2003) tried to run Turkey's optimum model by using Turkey's default risk, short-term capital flows, opportunity and reserve depletion costs, marginal propensity to import and time deposits. He tested whether the optimum reserve level differed significantly from CBRT's reserves in the period of 1988-2002 by comparing the CBRT's optimum reserve level which was calculated for the quarterly periods with the reserves in the relevant period. The results of the model indicated that Turkey's international reserves were higher than optimum reserve levels in the period of 19882002. It was also found that the exchange rate system was a key determinant of reserve level in Turkey and there was less reserve requirement in the floating exchange rate regime.

Garcia and Soto (2004) empirically evaluated the contribution of international reserves in minimizing the risk of a currency crisis. They found that the ratio of reserves to short-term debt was strong in explaining international crisis, even after checking for financial development and political variables. They computed the optimal level of reserves for a group of East Asian economies and for Chile based on their estimates on crisis probabilities. They concluded that the current reserve levels for most of the cases were consistent with an optimal self insurance policy under plausible presumptions concerning the cost of a crisis. According to Garcia and Soto, a country's economy was considered to be sound when the foreign exchange reserves of this country corresponded to an amount to cover the external debt due within one- year period.

Park and Estrada (2009) examined that whether reserves in developing Asia countries reached excessive levels or not by employing panel data analysis based on Edison (2003) for the period of 1980-2004. The results of the analysis indicated that the reserve levels in the region were large and excessive since 2002 and were considerably above the reserve levels that could be attributed to macroeconomic indicators. They also found that there were substantial differences across countries in the size and timing of excess reserves and the overall pattern signaled to large and growing excess reserves especially since 2003.

Bernard (2011) carried out several methodologies for evaluating the reserve adequacy in Central America and comparator group of emerging market economies in the period of 1993-2008 taking into consideration the high degree of deposit dollarization in the region. He found that reserve cover was low both in an absolute and relative sense, suggesting further reserve accumulation was 
an important policy alternative for diminishing vulnerabilities. After using the variables of current account position, openness of an economy, financial depth, foreign exchange rate flexibility and external debt stock as well as reserve levels, the results of the analysis showed that the reserves of the region scored relatively low compared to the other emerging market economies. In addition, it was also found that Central American countries took into account the reserve accumulation of the large emerging market economies in Latin America when making policy decisions.

Mwase (2012) investigated the driving factors of reserves in emerging market economies and small islands and developed an operational metric for estimating reserves in small islands taking into consideration their unique characteristics. By using quantile regression techniques to allow the estimated factors driving reserve holdings to vary along the reserve holding distribution, he found that the metric performed better than existing metrics in reducing crisis probabilities in small islands. The findings suggested that imports and exchange rate volatility were key drivers of reserve holdings in small islands while imports and financial depth were the important factors in emerging market economies. According to the results, economies with higher import shares kept higher reserves suggesting that vulnerability to current account shocks could be an important determinant of reserve holdings. Furthermore, small islands with more flexible exchange rate regimes tended to hold less reserves and emerging market economies with higher broad money to GDP tended to hold higher reserves.

Csávás and Csom-Bíró (2017) tested to what extent the indicators related to reserve adequacy applied by the IMF and investment banks could be mapped with those proposed in the academic literature by collecting a broad database, which covered more than 100 countries, based on the IMF's regular country reports. They found that the IMF tended to use the monetary aggregate indicators and short-term external debt more often with the increase in income, while the role of the import rule gradually decreased as a function of income. According to their findings, there was a positive relationship between the import rule and use of capital controls. In addition, for countries which implement fixed exchange rate regime, the import and monetary aggregate indicators were used more often than for the countries which implement floating exchange rate regime, while the use of shortterm external debt was less frequent.

Eren (2017) tried to assess reserve demand of 17 developing countries that implement floating exchange rate regime by using panel data method with pooled ordinary least squares and fixed effects estimators in the period of 2001-2015. He developed an alternative metric to measure reserve adequacy for countries studied based on the panel data results. After taking into account only the fixed effects on country basis, the results of the analysis indicated that while portfolio liabilities representing short term external debt, the broad money supply reflecting domestic risks, the export volatility and foreign exchange rate volatility reflecting external balance risk were positive and significant, U.S.A interest rate reflecting the opportunity cost of holding reserve seemed negative and significant.

\section{ECONOMETRIC ANALYSIS}

\section{II.I. Data and Methodology}

In this study, the reserve adequacy in Turkey has been tried to be analysed. When checked the studies regarding reserve adequacy, it has been seen limited studies focusing on this issue in Turkey. Therefore, the causality relationship between the international reserves, central bank reserves and the optimum import level are examined with the help of empirical analysis in this section. The period ranges from 2011:Q3 to 2018:Q4 which covers the 2016-2018 period in which the volatility and currency fluctuations increased dramatically in the financial markets and the CBRT had to use its reserves significantly to stabilize the foreign exchange rates. In investigation of the relationship among variables, Fourier KPSS unit root test and Fourier Granger causality test are employed by using quarterly data which are obtained from the CBRT EVDS have been used. 
Table 1: Variables and Expected Relationship

\begin{tabular}{llll}
\hline & Variables & Measure & Expected Relationship \\
\hline Independent var(1) & Optimum import level & $\begin{array}{l}\text { \%25 of annual import } \\
\text { Short-term debt which will be } \\
\text { repaid in one-year }\end{array}$ & $(+)$ \\
Independent $\operatorname{var}(2)$ & Short-term external debt & International reserves & $(+)$ \\
Dependent $\operatorname{var}(1)$ & Reserves 1 & Net international reserves & $(+)$ \\
Dependent $\operatorname{var}(2)$ & Reserves 2 & & $(+)$ \\
\hline
\end{tabular}

In the first stage, Fourier KPSS unit root test has been used to check the stationary of the variables. The Fourier KPSS test developed by Becker et al (2006) can both detect sudden and slow changes. In addition, it seems that the position, number and form of structural changes do not affect the power of the test. Subsequently, Fourier Granger causality test, a new methodology proposed by Ender and Jones (2016) with a Fourier approximation, has been employed to investigate the causality relationship between variables. When the Fourier terms are used to control for breaks, the Granger causality results differs from those documented before in various important ways. In contrast to the Granger-causality results indicated by the linear VAR, when Enders and Jones (2016) put trigonometric functions into the model, they detect stronger relations and richer sets of interactions between the variables.

\section{II.II. Analysis and Results}

Since there is generally no specific information relating to the definite nature of the breaks and no practical knowledge about the location and the number of breaks to use in testing for stationary, using an incorrect specification for the number or form of breaks might create some dilemma such as ignoring the breaks together. Becker et al (2006) developed a stationary test in which a chosen frequency component of a Fourier function was used to estimate the deterministic components of the model. A Fourier series could effectively model the behavior of an unknown function even though this function is not regular. In this stationary test, that the Fourier function capturing the movements of the unknown function is the primary reason for applying it. The Fourier KPSS unit root test developed by Becker et al (2006) can capture not only sudden changes but also slow changes and the position, number and form of structural changes do not affect the power of the test. For this reason, the performance of the tests was substantially robust to several kinds of structural breaks often seen in economic analysis, including the breaks of opposite signs (Tsong et al, 2016).

The methodology developed by Becker et al (2006) seems strong to notice sharp and u-shaped breaks as well as smooth breaks near the end of a series and it performs well when breaks are gradual. Becker et al (2006) employ trigonometric terms to capture unknown nonlinearities. The test they developed is a KPSS-type stationary test (Becker et al, 2006).

Becker et al (2006) take into account the following DGP;

$$
\begin{aligned}
& y_{t}=X t^{\prime} \beta+Z t^{\prime} \gamma+r_{t}+\varepsilon_{t} \\
& r_{t}=r_{t-1}+u_{t},
\end{aligned}
$$

where $\varepsilon$ are stationary errors and ut are independent and identically distributed with variance $\sigma_{\mathrm{u}}{ }^{2}$. It is chosen $\mathrm{Zt}=[\sin (2 \pi \mathrm{kt} / \mathrm{T}), \cos (2 \pi \mathrm{kt} / \mathrm{T})]^{\prime}$ to capture a break in the deterministic term, where $\mathrm{k}$ represents the frequency and $\mathrm{T}$ is the sample size. Here, to test whether yt is stationary or not, it is defined as $\mathrm{Xt}=[1]$ for a level-stationary process for $\mathrm{yt}$ and $\mathrm{Xt}=[1, \mathrm{t}]^{\prime}$ for a trend-stationary process.

At the start, one of the models described below is estimated and the residuals are obtained, in order to acquire the t-statistic required for testing the null hypothesis $\left(\mathrm{H} 0=\sigma_{\mathrm{u}}{ }^{2}=0\right)$;

$$
\begin{aligned}
& y_{t}=\alpha_{0}+\gamma_{1} \sin \left(\frac{2 \pi k t}{T}\right)+\gamma_{2} \cos \left(\frac{2 \pi k t}{T}\right)+e_{t} \\
& y_{t}=\alpha_{0}+\beta t+\gamma_{1} \sin \left(\frac{2 \pi k t}{T}\right)+\gamma_{2} \cos \left(\frac{2 \pi k t}{T}\right)+e_{t}
\end{aligned}
$$


The following test statistics is obtained;

$$
\tau_{\mu}(\mathrm{k}) \text { or } \tau_{\tau}(\mathrm{k})=\frac{1}{\mathrm{~T}^{2}} \frac{\sum_{\mathrm{t}=1}^{\mathrm{T}} \tilde{\mathrm{S}}_{\mathrm{t}}(\mathrm{k})^{2}}{\widetilde{\sigma}^{2}}
$$

where $\widetilde{\mathrm{S}}_{\mathrm{t}}(\mathrm{k})=\sum_{\mathrm{j}=1}^{\mathrm{t}} \tilde{\mathrm{e}}_{\mathrm{j}}$ and $\tilde{\mathrm{e}}_{\mathrm{j}}$ denote the OLS residuals from the regression (2) for $\tau_{\mu}(\mathrm{k})$ or (3) for $\tau_{\tau}(\mathrm{k})$. As in KPSS, a nonparametric estimate $\widetilde{\sigma}^{2}$ of the long-run variance could be acquired by selecting a truncation lag parameter 1 and a set of weights $w j, j=1, \ldots, l$;

$$
\widetilde{\sigma}^{2}=\tilde{\gamma}_{0}+2 \sum \mathrm{w}_{\mathrm{j}} \tilde{\gamma}_{\mathrm{j}},
$$

where $\tilde{\gamma}_{j}$ refers the jth sample auto-covariance of the residuals $\tilde{e}_{t}$ from equation (2) or (3).

To determine the optimal number of $\mathrm{k}$, the value which gives the minimum sum of residuals (OLS) is being selected. In case the non-linear trend is not present in DGP, it can be applied the standard KPSS test in order to obtain increased power. As it seems useful to test for the absence of a non-linear trend, Becker et al (2006) proposed that F-test statistic to be used. Therefore, the following F-test statistic for this hypothesis (absence of a nonlinear trend (i.e. $\gamma 1=\gamma 2=0$ ) can be calculated against the alternative of a nonlinear trend with a given frequency $\mathrm{k}$.

$$
\mathrm{F}_{\mathrm{i}}(\mathrm{k})=\frac{\left(\mathrm{SSR}_{0}-\mathrm{SSR}_{1}(\mathrm{k})\right) / 2}{\mathrm{SSR}_{1}(\mathrm{k}) /(\mathrm{T}-\mathrm{q})} \quad \mathrm{i}=\mu, \tau,
$$

The F-test could be used only if the null of stationary is rejected. The standard KPSS test statistic would be used in case trigonometric terms are not significant. In comparison with the critical values related to Fourier Test which are shown in the study of Becker et al (2006), the results of the stationary test are stated below;

Table 2: Fourier KPSS Unitroot Test Results $(\mathrm{T}=30)$

\begin{tabular}{lcccc}
\hline Variable & Frequency & MinSSR & FKPSS & F-Statistic \\
\hline Logimport & 1 & 0.136384 & 0.083684 & 9.87 \\
Logshort-term & 2 & 0.142595 & 0.511985 & 7.49 \\
Logintreserve & 1 & 0.101737 & 0.241385 & 12.77 \\
Lognetintreserve & 1 & 0.150745 & 0.101964 & 29.66 \\
\hline
\end{tabular}

Notes: For the Fourier KPSS unit root test developed by Becker et al (2006), the critical values for Frequency $1 ; 0.2699,0.1720,0.1318$ and for Frequency $2 ; 0.6671,0.4152,0.3150$ at $1 \%, 5 \%, 10 \%$, respectively. And, the F-statistic critical values are $6.73,4.92$ and 4.13 at $1 \%, 5 \%, 10 \%$, respectively.

As seen in the Table 2, the variables are stationary. According to the F-test results which are used to test the significancy of the trigonometric terms, it seems that trigonometric terms for both variables are significant when the values are compared with the F-statistic critical values which are shown in the study of Becker et al (2006). In the graphs below, it is seen that the series belonged to the variables are stationary. 
Graph 1: International reserves, imports, net international rezerves and short-term external debt

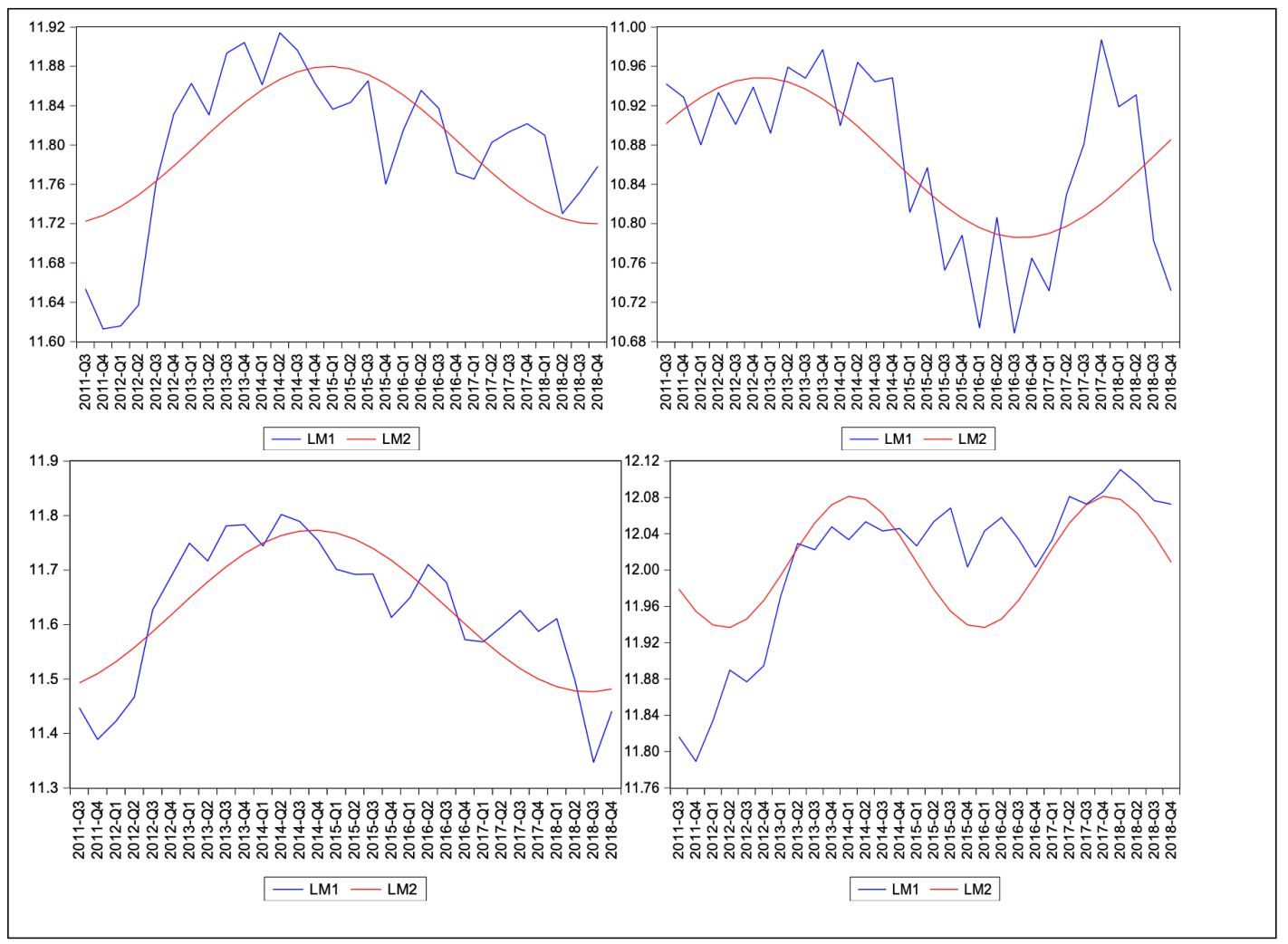

In the second stage, Fourier Granger causality test proposed by Enders and Jones (2016) is employed in this study in order to investigate the causal linkages between the variables. Since the linkages between the variables are subjected to gradual shifts and linear specifications are generally improper to detect the relationships, it is seen that econometric examinations are not generally direct and simple. Enders and Jones (2016) allows the Flexible Fourier form to catch the multiple smooth mean shifts which are probably to be present in the VAR system. In this regard, their results complement those of Enders and Holt (2014) who approximate a VAR with LSTAR mean shifts. While they concentrate on long-term mean shifts, Enders and Jones focus on Granger-causality tests and on the short-term dynamics of the system.

Rather than estimating the size, number and form of the breaks, Enders and Jones test the Flexible Fourier Form to control for breaks in a VAR and after they try the non-stationary of variables, they consider the linear VAR as following;

$$
\mathrm{z}_{\mathrm{t}}=\delta+\sum_{\mathrm{i}=1}^{11} \mathrm{~A}_{\mathrm{i}} \mathrm{z}_{\mathrm{t}-\mathrm{i}}+\mathrm{e}_{\mathrm{t}}
$$

where $\delta$ is a $(4 \times 1)$ vector of intercepts, $A_{i}$ is a $(4 \times 4)$ coefficient vector and $e_{t}$ is the vector of innovations. Although the responses seem sensible, they have some complications for two reasons. First, to the extent that there are neglected structural breaks, the system given by (7) is misspecified. Second, given that an unrestricted VAR is probably to be overparameterized, the confidence intervals presented in the figure may be redundantly large. In order to show how neglected breaks can interfere with Granger causality tests, they pursue a standard recommendation and restrict the VAR by imposing the limitations indicated by the Granger causality tests. Their results show that there is very little interaction among the variables. The critical responses are such that series tend to react only to their own shocks.

Then, Enders and Jones allow the deterministic regressors be as following, instead of the VAR given by equation (7);

$$
\mathrm{z}_{\mathrm{t}}=\delta(\mathrm{t})+\sum_{\mathrm{i}=1}^{11} \mathrm{~A}_{\mathrm{i}} \mathrm{z}_{\mathrm{t}-\mathrm{i}}+\mathrm{e}_{\mathrm{t}}
$$




$$
\delta(\mathrm{t})=\left[\delta_{1}(\mathrm{t}), \delta_{2}(\mathrm{t}), \delta_{3}(\mathrm{t}), \delta_{4}(\mathrm{t})\right]^{\prime}
$$

and each intercept $\delta_{\text {it }}$ depends on $n$ Fourier frequencies such that;

$$
\delta_{i}(t)=a_{i}+b_{i} t+\sum_{k=1}^{n} a_{i k} \sin \left(\frac{2 \pi k t}{T}\right)+b_{i k} \cos \left(\frac{2 \pi k t}{T}\right)
$$

When the Fourier terms are included to control for breaks, the Granger causality results differ from those acquired before in various important ways. In opposition to the Granger-causality results indicated by the linear VAR, when Enders and Jones (2016) put trigonometric functions into the model, they detect stronger relations and richer sets of interactions between the variables.

Table 3: Causality Test Results( $\mathbf{T}=\mathbf{3 0})$

\begin{tabular}{lllll}
\hline Relationship & Wald-stat & Asymptotic p-value & Bootstrap p-value & Optimal Lag \\
\hline 1 & 7.790 & 0.020 & 0.036 & 2 \\
2 & 13.925 & 0.001 & 0.006 & 2 \\
3 & 12.346 & 0.136 & 0.382 & 8 \\
4 & 14.096 & 0.050 & 0.370 & 7 \\
\hline
\end{tabular}

1 - International reserves $\rightarrow$ Imports (\%25 of annual import), Single frequency

2 - International reserves $\rightarrow$ Imports (\%25 of annaul import), Cumulative frequency

3 - Net international reserves $\rightarrow$ Short-term external debt, Single frequency

4- Net international reserves $\rightarrow$ Short-term external debt, Cumulative frequency

Notes: $\rightarrow$ denotes to causality. Optimal k (frequency) and p (lag) are determined by Akaike information criterion. Bootstrap p-values are based on 1000 replications. Because $\mathrm{n}<50$ in this study, we will take bootstrap p-value in comparison.

Table 3 shows the results of Fourier Granger causality test. According to the results, in the relationship 1 and 2, as bootstrap p-value is less than the critical value of 0.05 , there seems to be a causality relationship between international reserves and imports. On the other hand, in the relationship 3 and 4 , it is seen that there is not a causality relationship between net international reserves and short-term external debt as bootstrap p-value is greater than the critical value of 0.05 . The findings indicate that while, the first measure which is defined as $\% 25$ of annual import is valid for Turkey, the second measure which is defined short-term external debt could not be satisfied. According to the first approach, Turkey's reserves are adequate but if the second approach is taken into consideration, it is seen that reserves are not adequate in Turkey in the period of 2011:Q32018:Q4.

\section{CONCLUSION}

Central banks accumulate foreign exchange reserves in order to give confidence to the financial markets, to carry out external debt service of the government, to support the monetary and foreign exchange policy. The CBRT also try to hold foreign echange reserves with the objective of maintaining foreign exchange liquidity against external shocks and avoiding from financial instability like the other central banks in emerging market economies. In case of problems about financing and liquidity, these foreign exchange reserves can supply foreign exchange liquidity and stabilize the value of the domestic currency. Therefore, foreign exchange reserves are defined a safety net to guard against currency instability. In this regard, it is essential that emerging market economies decide which level of foreign exchange reserves is adequate in order to guard their local currency against fluctuations in foreign monetary policy and liquidity. 
When analysed the reserve position of Turkey in the period of 2011:Q3-2018:Q4, it is observed that the international reserves maintain their gradually increasing trend. According to the data obtained from the CBRT, total international reserves are 110.504 million U.S. dollar as of 2011 and 130.387 million U.S. dollar as of 2018, respectively. One of the traditional criteria developed by the IMF is to compare the reserve level with a spesific proportion (\%25) of annual import which is called optimal reserve level and the second approach is to compare the net reserve level with shortterm external debt. Therefore, the objective of this study is to analyse the causality relationship between the reserves, optimal reserve level and short-term external debt by employing Fourier KPSS unit root test and Fourier Granger causality test by using the quarterly data obtained from the CBRT EVDS.

The results of the analysis indicate that while there is a relationship between international reserves reserves and optimal reserve level (\%25 of annual import) which is used as a traditional appproach by the IMF, thereby supporting the reserves adequacy in Turkey, there is not a relationship between net international reserves and short-term external debt which is used as another approach by the IMF, thereby signaling to inadequacy of reserves in the period of 2011:Q3-2018:Q4. Given the fact that adequate reserve level is an important policy option for maintaining financial stability and reducing vulnerability of a country to financial fluctuations, Turkey has to increase its reserves to minimize the adverse effects of currency shocks and to increase the resistance against financial fluctuations.

\section{REFERENCES}

Bernard, K. M. (2011). International Reserve Adequacy in Central America. IMF Working Paper Series, No: 144. https://www.imf.org/external/pubs/ft/wp/2011/wp11144.pdf

Becker, R., Enders, W. \&Lee, J. (2006). A Stationarity Test in the Presence of an Unknown Number of Smooth Breaks, Journal of Time Series Analysis, 3(5): 381-409.

Calvo, A. G., Izquierdo, A. \& Rudy, L. (2012). Optimal Holding of International Reserves: Self-Insurance Against Sudden Stop, NBER Working Papers, No: 18219. https://www.nber.org/papers/w18219

CBRT (2019). Electronic Data Delivery System, https://evds2.tcmb.gov.tr/index.php?

Csávás, C. \& Csom-Bíró, G. (2017). Indicators Used for the Assessment of the Reserve Adequacy of Emerging and Developing Countries-International Trends in the Mirror of Theories, Financial and Economic Review, 16(1), 5-45.

Davis, J. S., Crowley, D. \& Morris, M. (2018). Reserve Adequacy Explains Emerging-Market Sensitivity to U.S. Monetary Policy, Economic Letter, Federal Reserve Bank of Dallas, https://www.dallasfed.org/ /media/documents/research/eclett/2018/el1809.pdf

ECB (2018). Economic Bulletin, Issue 8. https://www.ecb.europa.eu/pub/economicbulletin/focus/2018/html/ecb.ebbox201808_01.en.html

Egilmez, M. (2017). Merkez Bankası Rezervleri Yeterli mi?, Kendime Yazllar, 10 Nisan 2017, http://www.mahfiegilmez.com/2017/04/merkez-bankas-rezervleri-yeterli-mi.html

Enders, W. \& Jones, P. (2016). Grain prices, oil prices and multiple smooth breaks in a VAR, Studies in Nonlinear Dynamics \& Econometrics, 20(4), 399-419.

Eren, B. (2017). Gelişmekte Olan Ülkelerde Rezerv Talebini Etkileyen Faktörler ve Rezerv Yeterliliği, Uzmanlık Yeterlilik Tezi. Türkiye Cumhuriyeti Merkez Bankası. http://www.tcmb.gov.tr/wps/wcm/connect/4da1ac52-bbb4-4cef-a37b-

84a1b14a026a/Bekir+Uzmanlık+Tezi-

23.10.2017.pdf?MOD=AJPERES\&CACHEID=ROOTWORKSPACE-4da1ac52-bbb4-4cef-a37b84a1b14a026a-m3fBagm

Fischer, S. (2001). Opening Remarks, IMF/World Bank International Reserves: Policy Issues Forum. https://www.imf.org/en/News/Articles/2015/09/28/04/53/sp042801

Garcia, P. \& Soto, C. (2004). Large Hoarding of International Reserves: Are They Worth It?, Central Bank of Chile Working Paper, No: 299, Central Bank of Chile. https://core.ac.uk/download/pdf/6360181.pdf

IMF (1993). International Monetary Fund: Balance of Payments Manual. https://www.imf.org/external/np/sta/bop/bopman.pdf 
IMF (2000). Debt and Reserve-Related Indicators of External Vulnerability. https://www.imf.org/en/Publications/Policy-Papers/Issues/2016/12/31/Debt-and-Reserve-RelatedIndicators-of-External-Vulnerability-PP84

IMF (2001). Reserve adequacy in Emerging Market Economies, IMF Working Papers, WP/01/43, https://www.imf.org/external/pubs/ft/wp/2001/wp01143.pdf

IMF (2005). Guidelines for Foreign Exchange Reserve Management: Accompanying Document and Case Studies. $\quad$ https://www.imf.org/en/Publications/Manuals-Guides/Issues/2016/12/30/Guidelines-forForeign-Exchange-Reserve-Management-Accompanying-Document-and-Case-Studies-17343

IMF (2011). Assessing Reserve Adequacy. https://www.imf.org/external/np/pp/eng/2011/021411b.pdf

Kilci, E. N. (2019). Analysis of the Causality Relationship between Brent Crude Oil Prices and Energy Import in Turkey Under Structural Breaks, Business and Economics Research Journal, 10(4), 777-788.

Movchan, V. (2002). Criteria for International Reserves' Adequacy: What Level of Reserves Does Ukraine Need? Institute for Economic Research and Policy Consulting, 11.

Mwase, N. (2012). How much should I hold? Reserve Adequacy in Emerging Markets and Small Islands. $I M F$ Working Paper Series, No: 205. https://www.imf.org/en/Publications/WP/Issues/2016/12/31/Howmuch-should-I-hold-Reserve-Adequacy-in-Emerging-Markets-and-Small-Islands-26191

Park, D. \& Estrada, G. B. (2009). Are Developing Asia's Foreign Exchange Reserves Excessive? An Empirical Examination. Asian Development Bank, Economics Working Paper Series, No: 170. https://www.adb.org/sites/default/files/publication/28389/economics-wp170.pdf

Shcherbakov, S. G. (2002). Foreign Reserves Adequacy: Case of China, Prepared for the Fifteenth Meeting of the IMF Committee on Balance of Payment Statistics, Canberra, Australia,

TCMB (2001). Türkiye Cumhuriyeti Merkez Bankası Kanunu.

TCMB (2011). Merkez Bankalarında Rezerv ve Risk Yönetimi, http://www.tcmb.gov.tr/wps/wcm/connect/4925cf22-00ff-415e-84ea-04d861c1315e/117.pdf?MOD=AJPERES\&CACHEID=ROOTWORKSPACE-4925cf22-00ff-415e-84ea$04 \mathrm{~d} 861 \mathrm{c} 1315 \mathrm{e}-\mathrm{m} 3 \mathrm{fB} 7 \mathrm{Ju}$

Yaman, B. (2003). Uluslararası Rezervler, Türkiye Içcin Rezerv Yeterliliği ve Optimum Rezerv Seviyesi Uygulaması, Uzmanlık Yeterlilik Tezi. Ankara: Türkiye Cumhuriyet Merkez Bankası. http://www3.tcmb.gov.tr/kutuphane/TURKCE/tezler/bulentyaman.pdf

Tsong, C.C., Lee, C.F., Tsai, L.J., Hu, T.C. (2016). The Fourier Approximation and Testing for the Null of Cointegration, Empirical Economics, 51(3), 1085-1113.

Wijnholds, J. Onno de Beaufort ve Kapteyn, Arend (2001), Reserve Adequacy in Emerging Market Economies, IMF Working Paper, No: 143.

Yilanci, V. (2017). Analyzing the relationship between Oil Prices and Economic Growth: A Fourier Approach, Econometrics and Statistics, 27 (2), 51-67. 